\title{
Oxidation of $\delta$-ALA-D and DTT Mediated by Ascorbic Acid: Modulation by Buffers Depends on Free Iron
}

\author{
João Batista Teixeira RochA, ${ }^{*}$ Leandro Ademar Lissner, Robson Luiz Puntel, Roselei Fachinetto, \\ Tatiana Emanuelli, Cristina Wayne Nogueira, and Félix Alexandre Antunes SoAres \\ Departamento de Química, Centro de Ciências Naturais e Exatas, Universidade Federal de Santa Maria; 97105-900, \\ Santa Maria, RS, Brasil. $\quad$ Received January 11, 2005; accepted May 13, 2005
}

\begin{abstract}
Ascorbic acid (AA) is one of the most important endogenous reducing agents and can participate in a variety of cellular events. In vitro, AA can act as a potent oxidant agent in the presence of free metals, promote modifications in protein structures and form reactive oxygen species during its oxidation. We have observed that $\mathbf{A A}$ (above $6 \mathrm{mmol} / \mathrm{l}$ ) inactivates $\delta$-aminolevulinate dehidratase $(\delta$-ALA-D), a sulfhydryl-containing enzyme and that the inhibitory action was considerably decreased when 3-morpholinepropanesulfonic acid buffer (MOPS-pH: $6.8 ; 100 \mathrm{mmol} / \mathrm{l})$ was used in the $\delta$-ALA-D activity assay instead of potassium phosphate buffer (PB-pH: 6.8; $100 \mathrm{mmol} / \mathrm{I}) . \delta$-ALA-D inhibition, probably, is mediated by the oxidation of -SH groups caused by the auto-oxidation of AA promoted by metals or another oxidizing system present in liver supernatants. This hypothesis was confirmed by studying dithiothreitol (DTT $-400 \mu \mathrm{mol} / \mathrm{l}$ ) oxidation, as a model of enzyme thiols, where we observed that the mechanism underlying DTT and $\delta$-ALA-D oxidation caused by ascorbate is the same. The difference observed between different buffers may be related to the oxidation of $\mathrm{Fe}$ (II) to $\mathrm{Fe}$ (III) that was more accentuated in PB than in MOPS buffer. The presence of ethilenediamintetraacetic acid (EDTA-100 $\mu \mathrm{mol} / \mathrm{l})$ and $\mathrm{Fe}$ (III) $(5 \mu \mathrm{mol} / \mathrm{l})$ stimulated DTT oxidation more in PB than in MOPS buffer. Deferroxamine (DF - $100 \mu \mathrm{mol} / \mathrm{l})$ considerably decreased DTT oxidation. Catalase $(0.4 \mathrm{mg} / \mathrm{ml})$ and Superoxide dismutase (SOD-300 U/ml) had only a modest effect on DTT oxidation. The present results suggest that $\delta$-ALA-D inhibition by AA is mediated primarily by the oxidized form of $\mathrm{AA}$ and reactive oxygen species play only a modest role in the process.
\end{abstract}

Key words $\delta$-aminolevulinate dehidratase ( $\delta$-ALA-D); ascorbic acid; free iron; thiol group; oxidation-reduction; free radical

Special attention has been given to reducing agents that can interfere in oxidative and reductive processes, particularly in pathological situations that favour the production of pro-oxidants. One of the most important endogenous reducing agents is ascorbic acid (AA). ${ }^{1-3)}$ This physiological antioxidant participates in a variety of cellular events, including the synthesis of collagen, carnitine, and neurotransmitters, the transformation of xenobiotics, the absorption of iron and the scavenging of oxygen free radicals. ${ }^{4-11)}$

In vitro, AA can act as a potent oxidant agent particularly in the presence of free metals such as iron and copper. ${ }^{12-15}$ ) It is reported that AA promotes degradative modifications in other proteins in vitro, in part by the formation of reactive oxygen species during its oxidation. ${ }^{16-18)}$ Of particular importance, AA and $\mathrm{H}_{2} \mathrm{O}_{2}$, in the presence of catalytic amounts of iron-EDTA, react to form $\mathrm{HO}^{\circ}$, which is extremely reactive and toxic to biological systems. ${ }^{19-25)}$

In a previous preliminary study using Fenton's reaction to produce hydroxyl radicals we observed that AA inactivates $\delta$-aminolevulinate dehidratase ( $\delta$-ALA-D) and that the inhibitory action of AA was considerably decreased when 3morpholinepropanesulfonic acid buffer (MOPS) was used in the $\delta$-ALA-D activity assay instead of potassium phosphate buffer (PB). The generation of radicals can affect the thiol groups of proteins. ${ }^{26-28)} \delta$-ALA-D is a sulfhydryl-containing enzyme which catalyses the asymmetric condensation of two molecules of $\delta$-aminolevulinic acid ( $\delta$-ALA) to porphobilinogen. ${ }^{29-31)}$ This condensation occurs via the formation of two successive Schiff-base intermediates and porphobilinogen is the precursor of the porphyrins. ${ }^{32)}$ Consequently, $\delta$-ALA-D activity is fundamental for oxidative metabolism. ${ }^{33-35)}$ Recent persuasive evidence from ours as well as other laboratories has indicated that $\delta$-ALA-D is extremely sensitive to oxidative stress and possibly to the free radicals which produce it. ${ }^{36-39)}$

As pointed out above, buffers can modify AA auto-oxidation, possibly by changing the concentration or redox state of transition metals in the medium and also by scavenging reactive oxygen species such as $\mathrm{HO}^{\circ}{ }^{40}$ ) The aim of the present study was to investigate both the mechanisms of $\delta$-ALA-D inhibition caused by AA as well as the protection afforded by MOPS buffer. Here we propose that $\delta$-ALA-D inhibition is mediated by the oxidation of $-\mathrm{SH}$ groups caused by the autooxidation of AA, which is catalysed by contaminating metals or another oxidizing system present in liver supernatants and not by the reactive oxygen species formed during AA autoxidation. This hypothesis was confirmed studying dithiothreitol (DTT) oxidation, as a model of the essential enzyme thiols.

\section{MATERIALS AND METHODS}

5-5'-Dithio-bis(2-nitrobenzoic) acid (DTNB), dithiothreitol (DTT), ascorbic acid (AA), iron sulfate, ethilenediamintetraacetic acid (EDTA), 3-morpholinepropanesulfonic acid (MOPS), potassium phosphate buffer (PB) and deferroxamine (DF) were obtained from Sigma (St. Louis, MO., U.S.A.). All other chemicals were of analytical grade and obtained from standard commercial suppliers.

Adult male Wistar rats (aged two months) from our own breeding colony were maintained in a conditioned room $\left(20-25^{\circ} \mathrm{C}\right)$ under natural lighting conditions with water and food (Guabi-RS, Brasil) ad libitum.

Rats were killed by decapitation. The liver was quickly removed, placed on ice and homogenized in 7 volumes $150 \mathrm{mmol} / 1 \mathrm{NaCl}$. The homogenate was centrifuged at $4000 \mathrm{~g}$ at $4{ }^{\circ} \mathrm{C}$ for $10 \mathrm{~min}$ to yield a low speed supernatant 
fraction $\left(\mathrm{S}_{1}\right)$ that was used for the enzyme assay.

Mammalian $\delta$-ALA-D activity was assayed by the method of Sassa ${ }^{41)}$ measuring the rate of product (porphobilinogen) formation, with the exception that $100 \mathrm{mmol} / \mathrm{PB}(\mathrm{pH} \mathrm{6.8)}$ ) or $100 \mathrm{mmol} / 1 \mathrm{MOPS}$ buffer (pH 6.8) and $2.5 \mathrm{mmol} / 1$ ALA were used. The reaction was started $10 \mathrm{~min}$ after the addition of the enzyme preparation by adding the substrate. Incubations were carried out for $1 \mathrm{~h}$ at $39^{\circ} \mathrm{C}$. In some experiments, DTT $(2 \mathrm{mmol} / \mathrm{l})$ was used as a protecting agent. Enzyme activity was calculated using the absorption coefficient $\left(6.1 \times 10^{4} \mathrm{M}^{-1}\right.$ $\mathrm{cm}^{-1}$ ) for the porphibilogen formed.

The oxidation rate of the thiol groups was determined according to Ellman's method, ${ }^{42)}$ by measuring the amount of free DTT sulfhydryl groups. The incubation was carried out in a reaction medium at $37^{\circ} \mathrm{C}$ with one of two different buffers, $100 \mathrm{mmol} / \mathrm{l} \mathrm{PB}$ (pH 6.8) or $100 \mathrm{mmol} / \mathrm{l}$ MOPS (pH 6.8) containing $400 \mu \mathrm{mol} / 1 \mathrm{DTT}$ and variable quantities of AA as described in the figures. At different times, 0, 30, 60 and $120 \mathrm{~min}$ aliquots of the reaction mixture were checked for the amount of -SH groups at $412 \mathrm{~nm}$ (absorption coefficient $1.36 \times 10^{4} \mathrm{M}^{-1} \mathrm{~cm}^{-1}$ ).

Iron in water and in solutions was determined by atomic absorption (limit of detection $0.1 \mu \mathrm{mol} / \mathrm{l}$ ). In all tested samples, the iron content was below this limit.

The product of AA oxidation was obtained by maintaining a $250 \mathrm{mmol} / 1$ solution at $25^{\circ} \mathrm{C}$ for $18 \mathrm{~h}$. The oxidation was monitored at $265 \mathrm{~nm}$ and after this period the residual quantity of AA was less then $0.5 \%$. We also tested the effect of buffer on AA oxidation and, in the presence of $100 \mathrm{mmol} / \mathrm{l}$ of MOPS or PB, the oxidation was considerably accelerated and less than $0.5 \%$ was detected after $4 \mathrm{~h}$ (data not shown).

The rate of $\mathrm{Fe}$ (II) oxidation was determined as previously described. $^{43)}$ In short, the reaction mixtures contained $100 \mathrm{mmol} / 1$ of PB, MOPS buffer or no buffer and $300 \mu \mathrm{mol} / 1$ $\mathrm{Fe}(\mathrm{II})$ freshly prepared.

Enzymatic assays were analyzed by two-way analysis of variance (ANOVA) [2(types of buffer $\times 5$ (concentration of AA). Differences between groups were considered to be significant when $p \leq 0.05$. Oxidations of DTT under distinct conditions were carried out by three-way ANOVA [2(without/with EDTA) $\times 2$ (without/with AA) $\times 4$ (time of sampling)] with the time factor treated as repeated measures.

\section{RESULTS}

AA caused a concentration dependent inhibition of $\delta$ ALA-D when the enzyme assay was carried out in PB or MOPS buffer $(p<0.01$ for the two buffers). However, the inhibitory potency of AA was higher in PB than in MOPS buffer $(p<0.01)$ (Fig. 1).

Oxidation of DTT under different conditions was lower in the presence of MOPS than in the presence of PB (Figs. 2A, C). AA and AA plus EDTA considerably stimulated DTT oxidation. However, the rate of DTT oxidation was increased when EDTA and AA were present simultaneously (Fig. 2). Inclusion of $\mathrm{Fe}$ (III) in the reaction medium tended to increase the oxidation of DTT (Figs. 2B, D). Nevertheless, as observed earlier, the oxidation of DTT in the presence of MOPS was less accentuated than in the presence of PB (Figs. 2B, D).

The role of free iron on DTT oxidation caused by AA was
Buffer effect

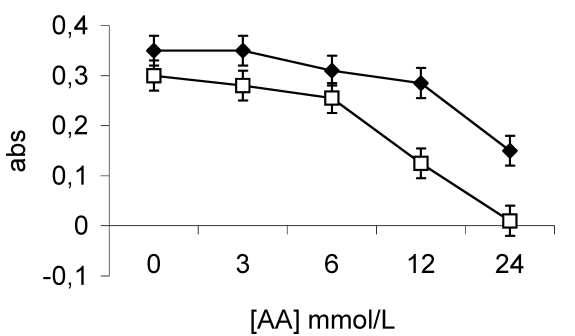

Fig. 1. Effect of Buffers on Rat Liver $\delta$-ALA-D Inhibition by AA

The supernatant fraction $\left(\mathrm{S}_{1}\right)$ was used for enzyme assay. Mammalian $\delta$-ALA-D activity was assayed by measuring the rate of porphobilinogen (PBG) formation at $555 \mathrm{~nm}$ in either $100 \mathrm{mmol} / 1 \mathrm{~PB}(\square)$ or $100 \mathrm{mmol} / 1 \mathrm{MOPS}(\bullet)$. The enzyme specific activity was $14.8 \mathrm{nmol} \mathrm{PBG} / \mathrm{h} / \mathrm{mg}$ protein for $\mathrm{PB}$ and $17.5 \mathrm{nmol} \mathrm{PBG} / \mathrm{h} / \mathrm{mg}$ protein for MOPS buffer. Data are expressed as mean \pm S.E.M. for $n=6$.
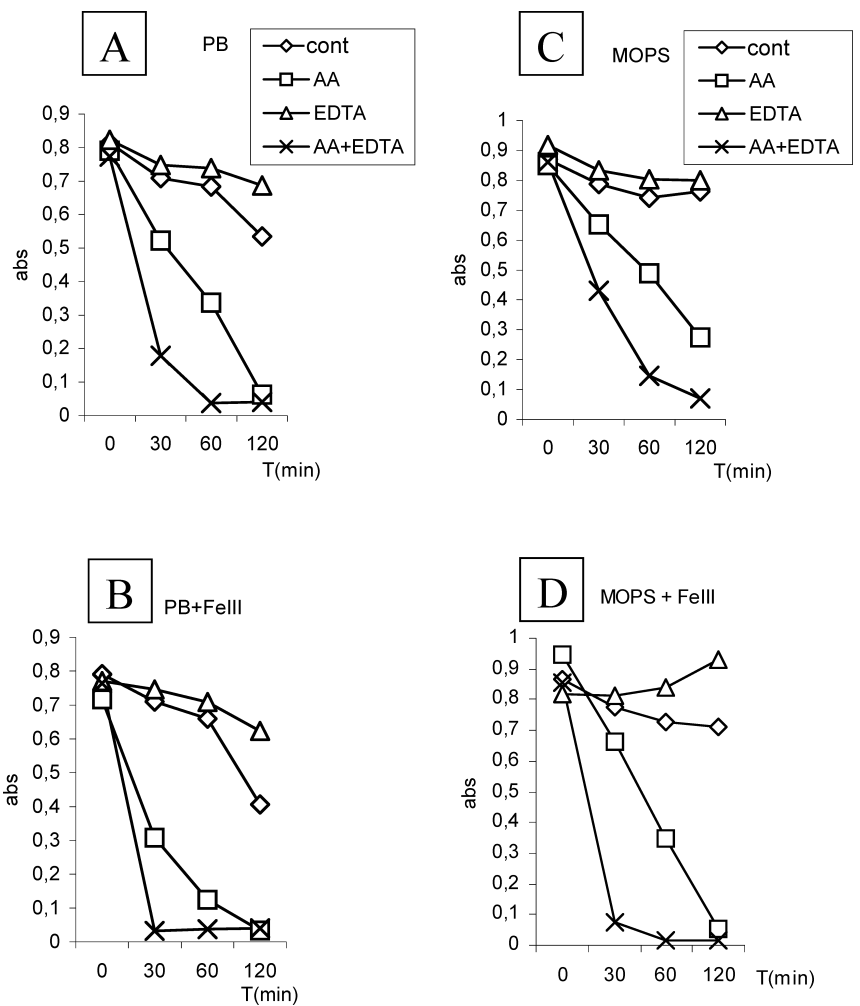

Fig. 2. Oxidation of DTT $(400 \mu \mathrm{mol} / \mathrm{l})$ Measured in the Presence of PB $(100 \mathrm{mmol} / \mathrm{l})(\mathrm{A}$ and $\mathrm{B})$ or in the Presence of MOPS $(100 \mathrm{mmol} / \mathrm{l})(\mathrm{C}$ and D)

EDTA $(100 \mu \mathrm{mol} / \mathrm{l})$; AA $(12 \mathrm{mmol} / \mathrm{l})$; in absence of Fe(III) (A and C) or in the presence of $\mathrm{Fe}(\mathrm{III})(5 \mu \mathrm{mol} / \mathrm{l})(\mathrm{B}$ and $\mathrm{D})$. The thiol oxidation rate was determined by measuring the amount sulfhydryl groups at different times $(0,30,60$ and $120 \mathrm{~min})$. Data are expressed as mean \pm S.E.M. for $n=4-5$.

confirmed by quantifying - $\mathrm{SH}$ oxidation in the presence of deferroxamine (DF) (Fig. 3). DF considerably decreased DTT oxidation both in the presence of PB or MOPS buffer.

Manitol (up to $800 \mathrm{mmol} / \mathrm{l}$ ) and DMSO (up to $10 \mathrm{mmol} / \mathrm{l}$ ) did not change the AA-stimulated oxidation of DTT (data not shown). AA-induced DTT oxidation in PB buffer was reduced by catalase $(p<0.05)$ and by catalase plus SOD $(p<0.05)$. At $30 \mathrm{~min}$, the content of $-\mathrm{SH}$ groups from DTT was $50 \%$ greater in the presence of catalase when compared to that measured in presence of AA. The content of $-\mathrm{SH}$ groups was about $30 \%$ in the presence of SOD and catalase. SOD alone did not significantly change the rate of DTT oxidation induced by AA (Table 1A). In contrast, AA-induced 
oxidation of DTT in MOPS buffer was not changed by catalase or catalase plus SOD and SOD alone increased DTT oxidation induced by AA (Table 1B). In the absence of AA, DTT oxidation was not changed by catalase, SOD or catalase plus SOD, regardless of the buffer used in the assay (Table $1)$.

To test the hypothesis that dehydroascorbic acid was the chemical form involved in the inhibitory effect of AA, we monitored the oxidation of AA at $265 \mathrm{~nm}$. After one day at $25^{\circ} \mathrm{C}$, the total concentration of AA was less than $99 \%$. The oxidation product of AA caused a pronounced inhibition of hepatic ALA-D and as observed with AA, the inhibitory potency in the presence of MOPS was less accentuated than that measured in PB $(p<0.01$; Fig. 4). It is noteworthy that the inhibitory effect caused by $12 \mathrm{mmol} / \mathrm{l}$ of oxidized product of AA was higher than that obtained with AA for both buffers tested (compare Fig. 4 with Fig. 1). DTT, a reducing agent that can protect ALA-D from oxidants, ${ }^{44,45)}$ caused an
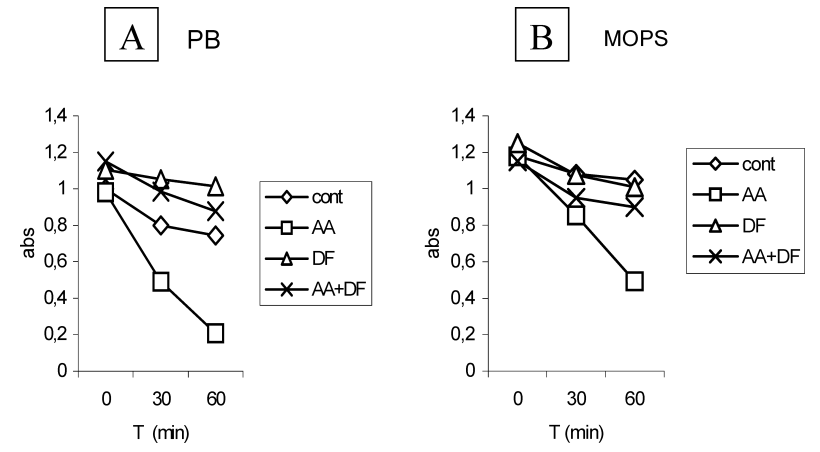

Fig. 3. Effect of Deferoxamine (DF) on DTT Oxidation Rate

The experiments were carried out in the presence of $\mathrm{PB}(100 \mathrm{mmol} / \mathrm{l})$ (A) or in the presence of MOPS $(100 \mathrm{mmol} / \mathrm{l})$ (B) without or with AA $(12 \mathrm{mmol} / 1)$; or DF $(100 \mu \mathrm{mol} / \mathrm{l})$. Data are expressed as mean \pm S.E.M. for $n=3$. increase of $40 \%$ in the activity measured in the presence of $\mathrm{PB}$, whereas the stimulation caused in the presence of MOPS was about $10 \%$. Furthermore, DTT protected ALA-D from $12 \mathrm{mmol} / 1 \mathrm{AA}$ oxidation product only when the assay was carried out in the presence of MOPS buffer ( $p<0.01$; Fig. 4).

To test whether the recycling of $\mathrm{Fe}(\mathrm{III})$ to $\mathrm{Fe}(\mathrm{II})$ by AA was involved in the oxidation of DTT and ALA-D, we determined the rate of $\mathrm{Fe}(\mathrm{II})$ oxidation in three different medium assays. In the presence of $\mathrm{PB}$, the oxidation of $\mathrm{Fe}(\mathrm{II})$ was considerably faster than that measured in the presence of MOPS or in the absence of buffers (Fig. 5, $p<0.01$ ). Data analysis also indicated that the oxidation of $\mathrm{Fe}(\mathrm{II})$ to $\mathrm{Fe}(\mathrm{III})$ was faster in the presence of MOPS buffer than in a non-

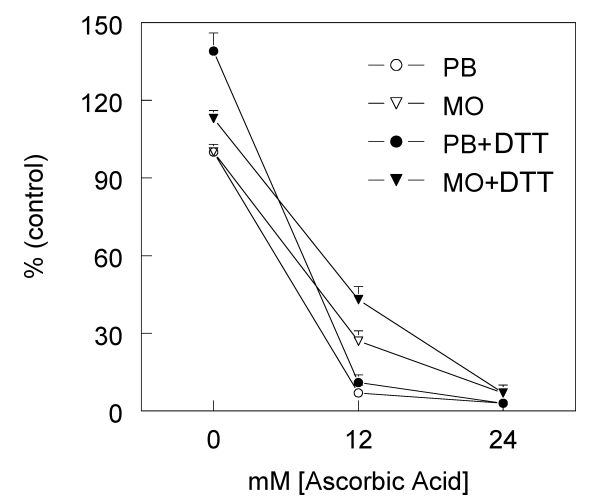

Fig. 4. Effect of Buffers on Rat Liver $\delta$-ALA-D Inhibition by the Product of AA Oxidation

A solution of AA was oxidized in air at $25^{\circ} \mathrm{C}$ for $18 \mathrm{~h}$ and then it was used to determine its inhibitory effect on the enzyme. The supernatant fraction $\left(\mathrm{S}_{1}\right)$ was used for enzyme assay. Mammalian $\delta$-ALA-D activity was assayed by measuring the rate of porphobilinogen (PBG) formation at $555 \mathrm{~nm}$ in $100 \mathrm{mmol} / 1 \mathrm{~PB}$ (PB) or $100 \mathrm{mmol} / 1 \mathrm{MOPS}$ (MO) in the presence $(2 \mathrm{mmol} / \mathrm{l})$ or in the absence of DTT. Enzyme specific activity $(100 \%)$ was $12.7 \mathrm{nmol} \mathrm{PBG} / \mathrm{h} / \mathrm{mg}$ protein for $\mathrm{PB}$ and $19.5 \mathrm{nmol} \mathrm{PBG} / \mathrm{h} / \mathrm{mg}$ protein for MOPS buffer. Data are expressed as mean \pm S.E.M. for $n=4$.

Table 1. Oxidation of DTT ( $400 \mu \mathrm{mol} / \mathrm{l})$ in Presence of PB (100 mmol/l) (A) and in Presence of MOPS (100 mmol/l) (B)

A) Oxidation of DTT ( $400 \mu \mathrm{mol} / \mathrm{l})$ in the presence of PB $(100 \mathrm{mmol} / \mathrm{l})$

\begin{tabular}{|c|c|c|c|c|c|c|}
\hline & \multicolumn{2}{|c|}{ Initial time } & \multicolumn{2}{|c|}{ Time $30(\mathrm{~min})$} & \multicolumn{2}{|c|}{ Time $60(\mathrm{~min})$} \\
\hline & Mean & \pm S.D. & Mean & \pm S.D. & Mean & \pm S.D. \\
\hline None & 0.694 & \pm 0.000 & 0.601 & \pm 0.002 & 0.514 & \pm 0.056 \\
\hline SOD & 0.690 & \pm 0.007 & 0.608 & \pm 0.005 & 0.533 & \pm 0.041 \\
\hline Catalase & 0.689 & \pm 0.007 & 0.619 & \pm 0.012 & 0.551 & \pm 0.026 \\
\hline $\mathrm{SOD}+$ Catalase & 0.676 & \pm 0.025 & 0.580 & \pm 0.048 & 0.525 & \pm 0.038 \\
\hline AA & 0.700 & \pm 0.004 & 0.242 & \pm 0.103 & 0.048 & \pm 0.045 \\
\hline $\mathrm{AA}+\mathrm{SOD}$ & 0.710 & \pm 0.047 & 0.280 & \pm 0.174 & 0.069 & \pm 0.066 \\
\hline $\mathrm{AA}+$ Catalase & 0.698 & \pm 0.023 & 0.363 & $\pm 0.038^{*}$ & 0.112 & \pm 0.030 \\
\hline $\mathrm{AA}+\mathrm{SOD}+\mathrm{Cat}$ & 0.690 & \pm 0.023 & 0.310 & $\pm 0.062 *$ & 0.079 & \pm 0.016 \\
\hline
\end{tabular}

B) Oxidation of DTT ( $400 \mu \mathrm{mol} / \mathrm{l})$ in the presence of MOPS ( $100 \mathrm{mmol} / \mathrm{l})$

\begin{tabular}{|c|c|c|c|c|c|c|}
\hline & \multicolumn{2}{|c|}{ Initial time } & \multicolumn{2}{|c|}{ Time $30(\mathrm{~min})$} & \multicolumn{2}{|c|}{ Time $60(\mathrm{~min})$} \\
\hline & Mean & \pm S.D. & Mean & \pm S.D. & Mean & \pm S.D. \\
\hline None & 0.660 & \pm 0.006 & 0.658 & \pm 0.045 & 0.597 & \pm 0.023 \\
\hline SOD & 0.651 & \pm 0.038 & 0.635 & \pm 0.086 & 0.587 & \pm 0.077 \\
\hline Catalase & 0.655 & \pm 0.019 & 0.668 & \pm 0.017 & 0.612 & \pm 0.026 \\
\hline SOD + Catalase & 0.643 & \pm 0.036 & 0.645 & \pm 0.021 & 0.580 & \pm 0.009 \\
\hline AA & 0.670 & \pm 0.089 & 0.605 & \pm 0.021 & 0.523 & \pm 0.042 \\
\hline $\mathrm{AA}+\mathrm{SOD}$ & 0.638 & \pm 0.002 & 0.520 & $\pm 0.044^{*}$ & 0.361 & $\pm 0.049 *$ \\
\hline $\mathrm{AA}+$ Catalase & 0.645 & \pm 0.021 & 0.608 & \pm 0.027 & 0.540 & \pm 0.031 \\
\hline $\mathrm{AA}+\mathrm{SOD}+\mathrm{Cat}$ & 0.640 & \pm 0.011 & 0.612 & \pm 0.024 & 0.491 & \pm 0.072 \\
\hline
\end{tabular}

The experiments was carried in the presence or absence of AA ( $12 \mathrm{mmol} / 1)$; in the presence of SOD $(300 \mathrm{U})$ and/or Catalase $(0.4 \mathrm{mg} / \mathrm{ml})$. The thiol oxidation rate was determined by measuring the sulfhydryl groups at different times $(0,30$ and $60 \mathrm{~min})$. The incubation was carried at $37^{\circ} \mathrm{C}$. Data are expressed as mean \pm S.E.M. for $n=5$. 


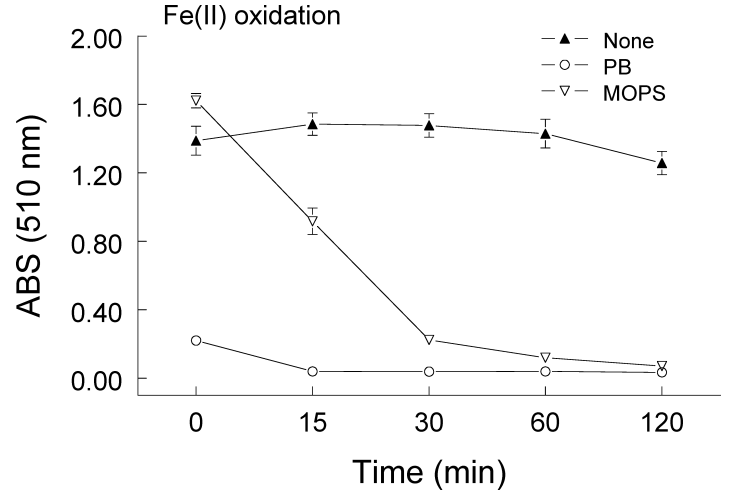

Fig. 5. Influence of Buffers on the Oxidation of Fe(II) Determined by the Complex Formation with ortho-Phenanthroline

Iron oxidation was determined in the presence of $100 \mathrm{mmol} / 1$ phosphate buffer (PB) or in the presence of MOPS buffer (MO). Experiments were also carried out in the absence of buffer. Data are expressed as mean \pm S.E.M. for $n=5$.

buffered medium ( $p<0.01$; Fig. 5).

\section{DISCUSSION}

AA inhibited $\delta$-ALA-D activity with higher potency when the assay was carried out in PB than when in MOPS buffer. Data obtained using DTT corroborated with the findings of $\delta$-ALA-D inhibition by AA. These results, together with previous studies from our laboratory, indicate that DTT is a simple model of mammalian $\delta$-ALA-D ${ }^{45,46)}$ and this is certainly related to the proximity of the thiol groups in DTT. Oxidation of the thiol groups of DTT promoted by AA was more accentuated when reactions were carried out in $\mathrm{PB}$ than in MOPS buffer. Auto-oxidation of DTT is rather complex and involves the formation of several intermediary species, including $\mathrm{HO}^{\circ}{ }^{47)}$ Consequently, we suppose that the mechanism underlying DTT and $\delta$-ALA-D oxidation caused by AA is, at least in part, the same. We propose the following two schemes to explain the oxidation of DTT promoted by AA:

$$
\begin{aligned}
& \text { Scheme 1. Direct oxidation of DTT by dehydroascorbate } \\
& \mathrm{AA}+\mathrm{Fe}(\mathrm{III}) \rightarrow \text { DEHYDROASCORBATE }+\mathrm{Fe}(\mathrm{II}) \\
& \mathrm{Fe}(\mathrm{II})+\mathrm{O}_{2} \rightarrow \mathrm{Fe}(\mathrm{III}) \\
& \text { DEHYDROASCORBATE + REDUCED DTT } \\
& \rightarrow \text { AA+OXIDIZED DTT } \\
& \text { or } \\
& \text { REDUCED DTT }+\mathrm{HO}^{*} \rightarrow \text { OXIDIZED DTT }+\mathrm{H}_{2} \mathrm{O}
\end{aligned}
$$

Ascorbic acid is oxidized to form dehydroascorbate, which can directly inhibit enzyme activity by oxidizing the $-\mathrm{SH}$ groups from the enzyme. This hypothesis is more plausible because catalase reduced DTT oxidation only when PB was used. Furthermore, classical $\mathrm{HO}^{\circ}$ radical scavengers (manitol and dimetilsulfoxide $)^{48)}$ had no protective effect in the rate of DTT oxidation (data not shown). In fact, Misra ${ }^{47)}$ postulated that during the auto-oxidation of DTT, the reaction of $2 \mathrm{O}^{2-}$. (superoxide) with $2 \mathrm{H}^{+}$can generate $\mathrm{H}_{2} \mathrm{O}_{2}$. The small effect of catalase and the absence of a protective effect of other $\mathrm{HO}^{\circ}$ radical scavengers is possibly related to a limited source of $\mathrm{H}_{2} \mathrm{O}_{2}$ in our assay systems. Thus, we postulated that the predominant pathway of DTT oxidation and, by analogy, of $\delta$ ALA-D inhibition involves the first set of reactions (Scheme 1). We confirmed this by determining the rate of $\mathrm{Fe}$ (II) oxidation in the two buffers and in the presence of PB the rate of iron oxidation was considerably increased. This oxidation is represented in the second equation of the above schemes and explains the source of oxidized iron (Fe(III) or other iron-oxygen complexes) that promptly oxidize AA to its oxidized form, particularly in PB. These results confirm previous studies of Kawano et al. where they found that phosphate induced lipid peroxidation in respiring mitochondria and to a lesser extent in non-respiring mitochondria. ${ }^{49)}$

The participation of dehydroascobic acid was also confirmed by the inhibitory action of the oxidation product of AA on $\delta$-ALA-D. Oxidized AA caused an inhibitory effect on enzyme activity that was higher than that obtained with AA. This effect was again more accentuated in PB than in MOPS buffer. Furthermore, DTT provided partial protection against the inhibitory action of oxidized AA on $\delta$-ALA-D, but this was only evident in the presence of MOPS. The partial protection of MOPS buffer and its absence in the case of PB is certainly related to the quantity of oxidant used (6 to 12 times that of DTT). These results confirmed that ascorbic acid and its oxidized form demonstrated greater inhibition of the enzyme in PB than in MOPS buffer. Similarly, Fiorani and collaborators have demonstrated that hexokinase inactivation by ascorbic acid/Fe(II) is mediated by dehydroascorbic acid and not by reactive oxygen species formed during ascorbic acid oxidation. ${ }^{50)}$

The oxidation of DTT via $\mathrm{HO}^{\circ}$ (Scheme 2) plays a secondary role in this process. The formation of $\mathrm{H}_{2} \mathrm{O}_{2}$ during the oxidation of ascorbic acid and the metal catalysed decomposition of hydrogen peroxide have been demonstrated by different laboratories. ${ }^{51,52)}$ One interesting finding of the present investigation was the fact that SOD increased the oxidation of DTT determined in MOPS buffer. The reasons for this effect are not clear to us but may involve the formation of $\mathrm{H}_{2} \mathrm{O}_{2}$ that in turn could play a part in the oxidation of DTT. In line with this, Misra has demonstrated that the auto-oxidation of DTT can be increased by SOD possibly by facilitating the formation of $\mathrm{H}_{2} \mathrm{O}_{2}{ }^{47)}$ Furthermore, the participation of $\mathrm{O}_{2}{ }^{-}$in the process of ascorbic acid oxidation is still elusive. ${ }^{53,54)}$ The difference observed between different buffers is probably due to differences in the capacity of the buffers to bind contaminating trace metals. In line with this, the inclusion of dexferoxamine in the incubation medium practically abolished the differences in the rate of DTT oxidation measured in the presence of PB and MOPS. The necessity of free iron as a determinant factor for ascorbic acid auto-oxidation is well documented in the literature and a variety of chelating agents can considerably reduce the rate of ascorbic acid oxidation. $^{12-15)}$ Furthermore, it has been reported that MOPS can chelate $\mathrm{HO}^{\cdot 39,55)}$ and this capacity may be an additional protective factor for DTT oxidation measured in the presence of AA.

In conclusion, the rate of DTT oxidation in the presence of ascorbic acid varied considerably depending on the buffer used (PB or MOPS). Based on the dexferoxamine experi- 
ment, we conclude that contaminating iron is the principal factor involved in DTT oxidation by dehydroascorbic acid and a secondary role for $\mathrm{HO}^{\circ}$ was also deduced from the catalase protective effect agains DTT oxidation measured in phosphate buffer. We also conclude that greater inhibitory effect of ascorbic acid towards $\delta$-ALA-D is related to the formation of more dehydroascorbic acid in the reaction medium when phosphate buffer was used instead of MOPS.

Acknowledgements This work was supported by CNPq, CAPES, FAPERGS and VITAE. J.B.T.R. is the recipient of CNPq research fellowship (523761/95-3 RE).

\section{REFERENCES}

1) Levine M., N. Engl. J. Med., 314, 892-902 (1986).

2) Frei B., Traber M. G., Redox Rep., 6, 5-9 (2001).

3) Proteggente A. R., Rehman A., Halliwell B., Rice-Evans C. A., Biochem. Biophys. Res. Commun., 277, 535-540 (2000).

4) Navas P., Villalba J. M., Córdoba F., Biochim. Biophys. Acta, 1197, $1-13$ (1997).

5) Rice M. E., Trends Neurosci., 23, 209-216 (2000).

6) Halliwell B., Trends Biochem. Sci., 24, 255-259 (1999).

7) Ginter E., Nutrition, 5, 369-374 (1989).

8) Karbownik M., Lewinski A., Reiter R. J., Int. J. Biochem. Cell Biol., 33, 735-753 (2001).

9) Mukhopadhyay C. K., Chatterjee I. B., Mrinal K. G., Mol. Cell Biochem., 142, 71-78 (1995).

10) Nandi A., Chatterjee I. B., J. Biosci., 11, 435-441 (1987).

11) Chakraborty D., Bhattacharyya A., Majumdar K., Chatterjee K., Chatterjee S., Sen A., Chatterjee G. C., J. Nutr., 108, 973-980 (1978).

12) Galley H. F., Davies M. J., Webster N. R., Free Rad. Biol. Med., 20, 139-143 (1996)

13) Zaleska M. M., Floyd R. A., Neurochem. Res., 10, 397-410 (1985).

14) Kagawa T., Takemura G., Qiu X. B., Maruyama R., Wang N. Y., Minatoguchi S., Fujiwara H., Int. Med., 41, 1213-1214 (2002).

15) Ahmad S., Kitchin K. T., Cullen W. R., Toxicol. Lett., 133, 47-57 (2002).

16) Herbert V., J. Am. Diet. Assoc., 93, 526-527 (1993).

17) Davies M. J., Dean R. T., Shanlin F., Biochem. J., 3005, 643-649 (1995).

18) Beber F. A., Wollmeister J., Brigo M. J. K., Silva M. C. J., Pereira C. N., Rocha J. B. T., Int. J. Vit. Nut. Res., 68, 181-188 (1998).

19) Winterbourn C. C., Biochem. J., 182, 625-628 (1979).

20) Winterbourn C. C., Biochem. J., 198, 125-131 (1981).

21) Sunderman F. W., Jr., Acta Pharmacol. Toxicol., 59, 248-255 (1986).

22) De Flora A., Benatti U., Morelli A., Guida L., Biochem. Int., 7, 281290 (1983)

23) De Flora A., Benatti U., Morelli A., Guida L., Biochem. Biophys. Res. Commun., 111, 980-987 (1983).

24) Halliwel B., Gutteridge J. M. C., "Free Radicals in Biology and Medi- cine," 3rd ed., Oxford University Press, Oxford, 1999.

25) Moskovitz J., Yim M. B., Chock P. B., Arch. Biochem. Biophys., 397, $354-359$ (2001).

26) Grunewald R. A., Brain Res. Rev., 18, 123-133 (1993).

27) Spear N., Aust S. D., Arch. Biochem. Biophys., 324, 111-116 (1995).

28) Yang E. Y., Campbell A., Bondy S. C., Redox Rep., 5, 371-375 (2000).

29) Gibson K. D., Neuberger A., Scott J. J., Biochem. J., 61, 618-629 (1955).

30) Shemin D., Phil. Trans. R. Soc. Lond., 273B, 109-115 (1976).

31) Bernard G. F., Itho R., Hohberger L. H., Shemin D., J. Biol. Chem., 252, 8965-8974 (1977).

32) Jaffe E. K., J. Bioenerg. Biomembr., 27, 169-179 (1995).

33) Beyersmann D., Cox M., Biochem. Biophys. Acta, 788, 162-168 (1984).

34) Gibbs P. N. B., Gore M. G., Jordan P. M., Biochem. J., 225, 573-580 (1985).

35) Chauhan S., O’Brian M. K., J. Biol. Chem., 270, 19823-19827 (1995).

36) Pande M., Flora S. J. S., Toxicology, 177, 187-196 (2002)

37) Flora S. J. S., Dubey R., Kannan G. M., Chauhan R. S., Pant B. P., Jaiswal D. K., Toxicol. Lett., 132, 9-17 (2002).

38) Folmer V., Soares J. C. M., Rocha J. B. T., Int. J. Biochem. Cell Biol., 34, 1279-1285 (2002).

39) Fernandez-Cuartero B., Rebollar J. L., Batlle A., de Salamanca R. E., Int. J. Biochem. Cell Biol., 31, 479-488 (1999).

40) Aust S. T., Welch K. D., Davis T. Z., Arch. Biochem. Biophys., 397, 360-369 (2002).

41) Sassa S., Enzyme, 28, 133-145 (1982).

42) Ellman G. L., Arch. Biochem. Biophys., 82, 70-77 (1959).

43) Puntel R. L., Nogueira C. W., Rocha J. B. T., Neurochem. Res., 30, 225-235 (2005).

44) Perottoni J., Meotti F. C., Folmer V., Pivetta L., Nogueira C. W., Zeni G., Rocha J. B. T., Env. Tox. Pharmacol., 19, 239-248 (2005).

45) Nogueira C. W., Zeni G., Rocha J. B. T., Chem. Rev., 104, 6255-6285 (2004).

46) Farina M., Barbosa N. B. V., Nogueira C. W., Folmer V., Zeni G., Andrade L. H., Braga A. L., Rocha J. B. T., Braz. J. Med. Biol. Res., 35, $323-331$ (2002).

47) Misra H. P., J. Biol. Chem., 249, 2151-2155 (1974).

48) Prabhu H. R., Krishnamurthy S., Indian J. Biochem. Biophys., 63, 54-57 (1993).

49) Kawano H., Kogure K., Fukuzawa K., Terada H., Biol. Pharm. Bull., 16, 1094-1098 (1993).

50) Fiorani M., De Sanctis R., Saltarelli R., Palma F., Ceccaroli P., Stocchi V., Arch. Biochem. Biophys., 334, 157-161 (1996).

51) Baker W. L., Talanta, 52, 425-433 (2000).

52) Nowak D., Piasecka G., Antczak A., Pietras T., Biomed. Biochem. Acta, 50, 265-272 (1991).

53) Nishikimi M., Biochem. Biophys. Res. Commun., 63, 463-468 (1975).

54) Halliwell B., Foyer C. H., Biochem. J., 155, 697-700 (1976).

55) Van Dyke B. R., Clopton D. A., Saltman P., Inor. Chimi. Acta, 242, 57-61 (1996). 